\title{
Functional and ultrastructural characteristics of two types of rat granulosa cell cultured in the presence of FSH or transforming growth factor $\alpha$ (TGF- $\alpha$ )
}

\author{
A. Sanbuissho, G. Y. Lee and E. Anderson* \\ Department of Anatomy and Cellular Biology, Harvard Medical School, Boston, MA 02115, USA
}

\begin{abstract}
Granulosa cells were isolated from 15-day-old, 25-day-old or PMSG-primed rats and were separated by Percoll gradient ( 20 to $60 \%$ ) into five fractions. The cells in fraction 2 were mostly small cells $(6.96-9.57 \mu \mathrm{m})$ and fractions 3 and 4 had a relatively high population of large cells $(10.96-13.05 \mu \mathrm{m})$ which were sorted to collect a pure population of large cells. Aliquots of small or large cells were cultured separately in serum-free defined DMEM/F-12 medium containing $50 \mathrm{ng} \mathrm{FSH} \mathrm{ml}{ }^{-1}$, or $10 \mathrm{ng}$ transforming growth factor $\alpha$ (TGF- $\alpha$ ) $\mathrm{ml}^{-1}$ for 3 days. In PMSG-primed rats, the large cells produced 3.2 -fold more progesterone than did small cells (with FSH/TGF $\alpha$ : $255 \pm 35.0$ versus $77.32 \pm 14.5 \times 10^{-6} \mathrm{ng}$, day 1). Large and small cells from 25-day-old rats produced similar amounts of progesterone (FSH/TGFa: $65.68 \pm 9.6$ versus $78.25 \pm 12.3 \times 10^{-6} \mathrm{ng}$, day 1 ). In 15 -day-old rats, large and small cells produced very low concentrations of progesterone (FSH/TGFa: $4.69 \pm 1.2$ versus $2.66 \pm 1.0 \times 10^{-6} \mathrm{ng}$, day 1). Large cells from PMSG-primed rats had characteristics of steroidogenic cells, i.e. smooth endoplasmic reticulum and well-developed mitochondria with tubular cristae compared with small cells, whereas small and large cells from 25- and 15-dayold rats contained the regularly occurring organelles without the endoplasmic reticulum of the smooth variety and mitochondria with lamellar cristae. This study shows that the heterogeneity of granulosa cells is related to size, metabolic response to FSH, TGF- $\alpha$ or to both factors and morphological features, all of which may be associated with the transition from preantral to preovulatory stages of follicle differentiation.
\end{abstract}

\section{Introduction}

Rat granulosa cells have been shown to consist of two distinct cell types that can be separated according to size (Telfer et al., 1988; Hartshorne, 1990; Vanderhyden et al., 1990; Rao et al,, 1991). Rao et al. (1991) consider that the two types of granulosa cell differ in their degree of differentiation, and that this is independent of the cell cycle within the follicle. The different characteristics of the two cell types seem to be important for follicular function(s); however, little is known concerning the function of these subpopulations of granulosa cells and whether they are related to the stages of follicular development. There is some evidence that mural granulosa cells contain more $\mathrm{LH}$ receptors than do the cumulus antral cells (Amsterdam et al., 1975; diZerega and Hodgen, 1980). Buccione et al. (1990) and Salustri et al. (1990) have pointed out that cumulus cells undergo FSH-dependent mucification, whereas mural granulosa cells do not.

Functional differences could be investigated if these cells were separated into relatively pure populations. Density gradient centrifugation (Lahteenmaki et al., 1982; Magoffin and Erickson, 1988) or flow cytometry (Hatfield and Hymer, 1986a; $1986 \mathrm{~b}$ ) is useful for separation and purification of living cells and have been applied to many types of cell including granulosa cells (Hirshfield et al., 1988), luteal cells (Ohara et al., 1987) and Leydig cells (Gale et al., 1982). Separation methods such as unit gravity sedimentation or Percoll gradient have yielded large cell preparations that are usually contaminated with small cells (Koos and Hansel, 1981). The combined use of density gradient and flow cytometry allows the isolation of fractions of highly purified luteal cells (Alila et al., 1988). We applied the techniques of density gradient and flow cytometry to rat granulosa cells in an attempt to separate them into subpopulations and examine further their structural and physiological features.

The specific aims of the present study were therefore (I) to apply the techniques of density gradient and flow cytometry to rat granulosa cells and (2) to assess the steroidogenic ability and morphological features of the two types of rat granulosa cell isolated from preantral, antral or preovulatory stage follicles cultured in the presence of FSH or transforming growth factor- $\alpha$ (TGF- $\alpha$ ) or both factors.

\section{Materials and Methods}

\section{Granulosa cell collection}

Sprague-Dawley rats were purchased from Taconic, Germantown, NY. Five rats were killed by cervical dislocation 
in each experiment when they were 15 and 25 days old, or injected with PMSG (15 iu per rat in $0.15 \mathrm{ml}$ saline; Sigma, St Louis, MO) when they were 23 days old and killed $50-52 \mathrm{~h}$ after the injection. Each experiment was repeated five times. Ovaries were removed and immediately immersed into McCoy's 5A medium (Irvine Scientific, Santa Ana, CA). The ovaries were punctured with fine needles and transferred into $2.0 \mathrm{ml}$ non-enzymatic cell dissociation solution (Sigma) for $10 \mathrm{~min}$; this method prevents the dissociation of thecal and stromal cells. In PMSG-primed rats, only large follicles (0.3$0.5 \mathrm{~mm}$ ) were punctured. The ovaries were then transferred to McCoy's 5A containing $0.5 \mathrm{~mol}$ sucrose $1^{-1}$ (Fisher Scientific,

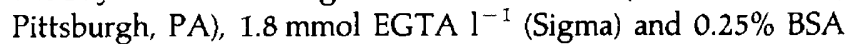
(Sigma) at $\mathrm{pH} 7.4$ and incubated at room temperature for $5 \mathrm{~min}$. The ovaries were pressed to release the granulosa cells into McCoy's 5A. The cell suspension was centrifuged at $200 \mathrm{~g}$ for $10 \mathrm{~min}$ and the pellet resuspended in McCoy's $5 \mathrm{~A}$. Cell viability was checked by Erythrosin B exclusion using a haemocytometer (Philips, 1973). Isolated granulosa cells were suspended in $1.5 \mathrm{ml} \mathrm{McCoy's} 5 \mathrm{~A}\left(4-5 \times 10^{6}\right)$.

\section{Percoll gradient and cell separation}

For preparation of the Percoll gradients, nine parts of Percoll (Pharmacia LKB Biotechnology, Piscataway, NJ) were mixed with one part of tenfold concentrated McCoy's $5 \mathrm{~A}$ medium to give an osmolality 310 mosmol $\mathrm{kg}^{-1}$. This mixture was diluted with McCoy's $5 \mathrm{~A}$ containing $0.25 \% \mathrm{BSA}$ to make various concentrations of Percoll solution. Two millilitres of $60 \%$ Percoll solution was pipetted into a sterile $18 \times 100 \mathrm{~mm}^{2}$ plastic centrifuge tube (Nalge Company, Rochester, NY). Two millilitres of $50 \%$ Percoll solution were then carefully layered on top of the $60 \%$ Percoll solution, followed by $2 \mathrm{ml}$ each of 40,30 , and $20 \%$ Percoll solution. Five tubes of Percoll gradient were used for preparations from 15-day-old rats, ten tubes for 25-day-old rats and 15 tubes for PMSG-treated rats. Up to $1.5 \mathrm{ml}$ of the crude cell suspension containing 3 to $5 \times 10^{6}$ cells $\mathrm{ml}^{-1}$ was layered onto the top of each gradient. The tubes were then centrifuged at $400 \mathrm{~g}$ for $10 \mathrm{~min}$ at $4^{\circ} \mathrm{C}$.

\section{Fraction collection}

Fractions were collected from the interphase of Percoll layers from the top of the tube using a Pasteur pipette. Sixty to eighty per cent of cells were recovered. Three fractions were pooled and diluted in 3-5 ml isotonic McCoy's 5A medium and centrifuged at $200 \mathrm{~g}$ for $10 \mathrm{~min}$. Finally, each fraction was resuspended and an aliquot $(50 \mu \mathrm{l})$ of each fraction was used for cell counting using a haemocytometer.

\section{Flow cytometry}

After separation by Percoll gradient, cells were analysed on forward angle light scatter (FALS; $1.0-19^{\circ}$ ) and light scatter (LS; 90 ) signals by an EPICS 750 series cell sorter (Coulter Electronics, Hialeah, FL) with an argon ion laser (Coherent Laser Division, Palo Seto, CA) tuned to the $488 \mathrm{~nm}$ line at $200 \mathrm{~mW}$. The FALS and $90^{\circ} \mathrm{LS}$ positions were adjusted to channels 3 to
64. The flow cytometer simultaneously sorted two populations of cells at a rate of 1000 cells $\mathrm{s}^{-1}$ with each sorting lasting 2-3 h. After sorting, cells in each fraction were recounted on a haemocytometer and cell viability determined.

\section{One-parameter analysis and cell sorting}

Distribution of small and large cells was demonstrated by FALS single parameter. A number of 10000 cells were counted in each fraction for analysing cell distribution. To determine the standard setting, a gate was placed on the nadir between the two populations of cells from 25-day-old rats. This gate setting was used for cell distribution of samples from 15-day-old and PMSG-primed rats.

\section{Quadrant analysis}

Distribution of pooled total cells was demonstrated by FALS-90 $0^{\circ}$ LS dual parameter. The FALS gate setting was the same place as one-parameter analysis and the $90^{\circ} \mathrm{LS}$ gate was placed on the centre of the maximum density of small cell population from 25-day-old rats. The gate settings were used for cell distribution of samples from 15-day-old and PMSG-primed rats. In this study, quadrants 1 and 2 contained high granularity of small and large cell populations, respectively, and quadrants 3 and 4 contained low granularity of small and large cell populations, respectively.

\section{Determination of cell size}

Cell diameters were recorded using a light microscope equipped with a micrometer.

\section{Cell culture}

The serum-free medium of Anderson and Lee (1993) for granulosa cell culture was used in this study. Attachmentpromoting substrate (E-C-L; UBI, Lake Placid, NY) was prepared by pretreating the surface of the culture wells. Solutions of E-C$\mathrm{L}\left(20 \mu \mathrm{g}\right.$ in $400 \mu \mathrm{l} \mathrm{H}_{2} \mathrm{O}$ ) were added to eight-well culture dishes (Nunc Inc., Napierville, IL) and incubated at $37^{\circ} \mathrm{C}$ for $24 \mathrm{~h}$. Aliquots were removed by aspiration before the addition of medium to the well. Small or large cells $\left(0.15 \times 10^{6} \mathrm{ml}^{-1}\right)$ were incubated in $0.5 \mathrm{ml} \mathrm{DMEM} / \mathrm{F} 12$ medium containing $5 \mu \mathrm{g}$ fibronectin $\mathrm{ml}^{-1}, 5 \mathrm{ng}$ selenium $\mathrm{ml}^{-1}, 40 \mathrm{ng}$ hydrocortisone $\mathrm{ml}^{-1}$, $2 \mu \mathrm{g}$ insulin $\mathrm{ml}^{-1}, 10 \mu \mathrm{g}$ transferrin $\mathrm{ml}^{-1}, 5 \mathrm{pg}$ triiodothyronine $\mathrm{ml}^{-1}, 10 \mu \mathrm{g}$ low-density lipoprotein $\mathrm{ml}^{-1}$ (LDL), $30 \mu \mathrm{g}$ highdensity lipoprotein $\mathrm{ml}^{-1}$ (HDL) and $10 \mu \mathrm{g}$ gentamicin $\mathrm{ml}^{-1}$ at $37^{\circ} \mathrm{C}$ under $5 \% \mathrm{CO}_{2}$ in air. All reagents were from Sigma except fibronectin (UBI, Lake Placid, NY). Steroid production is affected by the number of cells present; similar numbers of cells from each population were therefore cultured. Media from these cultures were removed $24 \mathrm{~h}$ later by gentle aspiration and replaced with $50 \mathrm{ng} \mathrm{FSH} \mathrm{mi}{ }^{-1}$ (oFSH-NIH-S9) or $10 \mathrm{ng}$ transforming growth factor- $\alpha \mathrm{ml}^{-1}$ (TGF- $\alpha$, rat; Bachem California, Torrance, CA) or a combination of both. The rationale for selecting FSH and TGF- $\alpha$ was from observation by Yeh et al. (1991), Anderson and Lee (1993), and Yeh et al. (1993). Granulosa cells were 
cultured for 3 days and the media were collected every $24 \mathrm{~h}$ for progesterone assay.

\section{Determination of progesterone production}

Culture media were assayed for progesterone by radioimmunoassay as described by Anderson et al. (1987). The sensitivity limit of the assay was $5 \mathrm{pg}$ per tube. Values are expressed per $10^{6}$ cells. The intra- and interassay coefficients of variation were $6.3 \%$ and $12.0 \%$, respectively.

\section{Ultrastructural analysis}

In some experiments, sorted cell fractions were collected for ultrastructure analysis. Cells were fixed with $2.5 \%$ glutaraldehyde (EMS, Fort Washington, PA) in 0.1 mmol sodium cacodylate $^{-1}$ $(\mathrm{NaCaC})$ buffer for 15 min, post-fixed with $1 \%$ osmium tetroxide $\left(\mathrm{OsO}_{4}\right)$ and processed according to Anderson et al. (1987). Thin sections were made and examined with a Phillips 300 electron microscope.

\section{Statistical analysis}

Steroid concentration in culture media, cell number and cell diameter were analysed by analysis of variance and Bonferroni test (Snedecor and Cochran, 1982). Differences were considered significant when $P<0.05$.

\section{Results}

\section{Cell separation by Percoll gradient}

By calibrating the density of the granulosa cells at various positions in the Percoll gradient (data not shown), solutions of Percoll with the specific gravity adjusted to 1.029 to $1.076 \mathrm{~g}$ $\mathrm{ml}^{-1}$ (20 to $60 \%$ Percoll) allowed granulosa cells to be separated into five fractions. No granulosa cells were separated beyond this range of densities. To determine the distribution of cells in the gradient, the number of cells from each fraction was recorded under a light microscope (Fig. 1). The diameters of granulosa cells were measured with a light microscope and the diameter of the two types of cell appeared to be constant among three groups (Table 1). Fraction 1 was discarded because it was composed mainly of damaged cells. Fraction 2 consisted of mainly small cells $(94.1 \pm 4.3 \%$ in 15-day-old rats, $84.5 \pm 4.5 \%$ in 25 -day-old rats and $91.0 \pm 7.2 \%$ in PMSGprimed rats) and these cells were cultured without sorting. Large cells were separated into incompletely resolved fractions; however, fractions 3 and 4 contained relatively large numbers of large cells $(39.1 \pm 3.5 \%$ in 15-day-old rats $65.0 \pm 5.0 \%$ in 25 -day-old and $42.1 \pm 4.2 \%$ in PMSG-primed rats). These fractions were sorted to obtain populations of purified large cells. Fraction 5 had relatively few cells. Blood cells formed a pellet at the bottom of the tubes and this was discarded.

\section{Flow cytometry}

The FALS signal is assumed to reflect cell size, whereas the $90^{\circ} \mathrm{LS}$ signal reflects internal structure such as cytoplasmic (a)

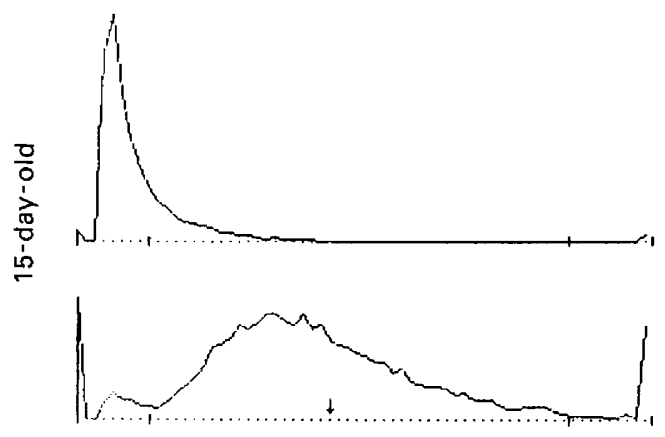

(b)

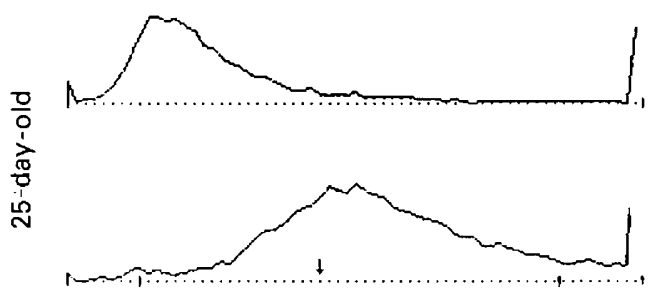

(c)

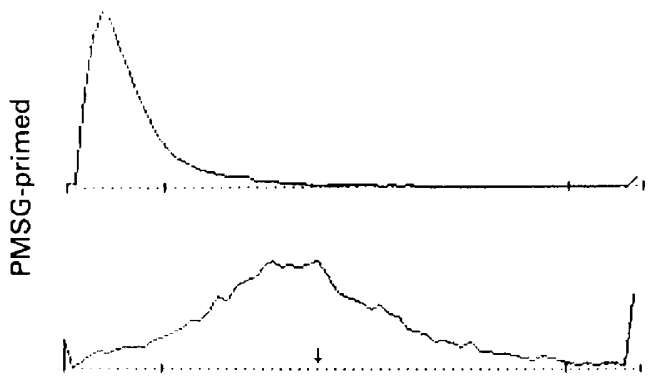

Fig. 1. The forward angle light scatter (FALS) analysis of small (upper panel) and large (lower panel) cell populations from (a) 15-dayold, (b) 25-day-old and (c) PMSG-primed rats. The FALS gate was set at channels 3-64 and the plots were generated from 10000 cells. The gate was placed on channel 28 ( $\downarrow$ ) for collecting further purified large cells.

Table 1. Comparison of diameters of small and large rat granulosa cells

\begin{tabular}{lcc}
\hline Animals & $\begin{array}{c}\text { Small } \\
(\mu \mathrm{m})\end{array}$ & $\begin{array}{c}\text { Large } \\
(\mu \mathrm{m})\end{array}$ \\
\hline 15-day-old & $8.84 \pm 0.71$ & $11.18 \pm 0.80$ \\
25-day-old & $8.95 \pm 0.56$ & $11.27 \pm 1.00$ \\
PMSG-primed & $8.96 \pm 0.60$ & $11.05 \pm 0.66$ \\
\hline
\end{tabular}

Cell diameter measured by a micrometer.

Values are means \pm SD diameter of $200-250$ cells. 
(a)

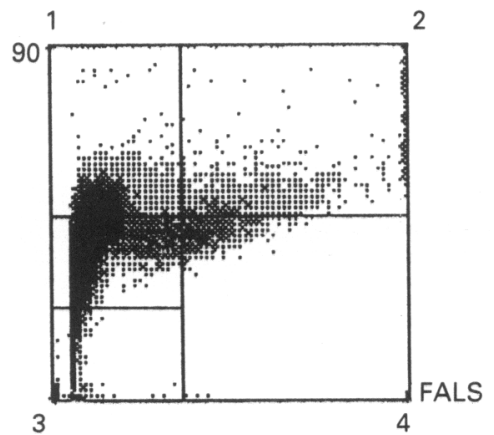

(b)

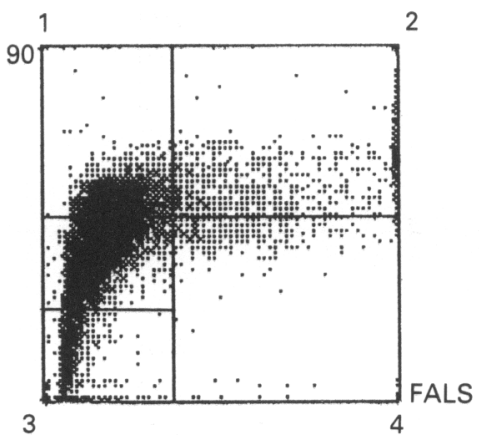

(c)

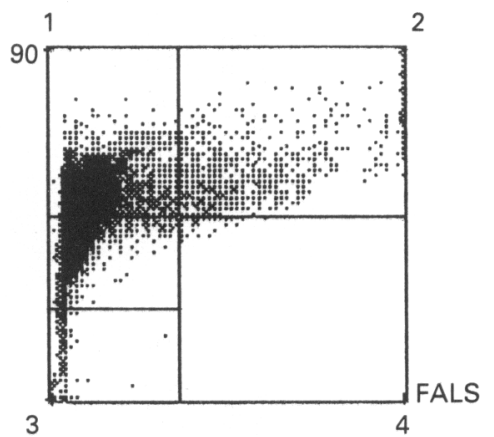

Fig. 2. Forward angle light scatter (FALS)- $90^{\circ}$ light scatter (LS) distribution (channel setting: FALS-23, $90^{\circ}$ LS-33). The plots were generated from 10000 granulosa cells from (a) 15-day-old, (b) 25-day-old and (c) PMSG-primed rats. The heavy dots represent most cells. Regions 1-2 and 3-4 are defined by $90^{\circ}$ LS and contain ridges of high and low cytoplasmic granularity. Regions 1-3 and 2-4 are defined by FALS and contain ridges of small and large cells. A lower ridge (channel 15; $90^{\circ}$ LS) in region 3 was eliminated because it consisted of cellular debris or red blood cells.

Table 2. Composition of large cells in total population of rat granulosa cells

\begin{tabular}{lcr}
\hline Animals & $\begin{array}{c}\text { Large cell } \\
(\%)\end{array}$ & \multicolumn{1}{c}{$\begin{array}{c}\text { Total cells } \\
\left(10^{6} \text { per rat }\right)\end{array}$} \\
\hline 15-day-old & $10.85 \pm 1.13$ & $0.61 \pm 0.08$ \\
25-day-old & $15.70 \pm 2.50$ & $6.76 \pm 0.22$ \\
PMSG-primed & $12.50 \pm 3.10$ & $10.81 \pm 1.04$ \\
\hline
\end{tabular}

Each value represents the mean \pm SD of measurements of two to three replicates.

Table 3. Quadrant analysis of granularity of rat granulosa cells

\begin{tabular}{lllllllll}
\hline & \multicolumn{3}{c}{ Small cells } & & \multicolumn{3}{c}{ Large cells } \\
\cline { 2 - 4 } \cline { 6 - 8 } Animals & Low & High & High:low & Low & High & High:low \\
& & & & & & & & \\
\hline \multirow{2}{*}{ 15-day-old } & 6324 & 1306 & 0.21 & & 612 & 672 & 1.10 \\
25-day-old & 5288 & 1979 & 0.37 & & 399 & 739 & 1.85 \\
PMSG-primed & 4582 & 4455 & 0.97 & & 54 & 678 & 12.56 \\
\hline
\end{tabular}

Small and large cells in regions (1), (2), (3) and (4) from Fig 2.

secretory granule content (Shapiro, 1985). One-parameter analysis showed the small cell (fraction 2) and large cell populations (fractions 3 and 4; Fig. 2). When cells from 25-day-old rats were used as a standard, the patterns of cell distribution from 15-day-old and PMSG-primed rats were different. The gate was placed on channel 23 (FALS) for calculating the percentage of small and large cell populations. In unseparated preparations of granulosa cells, the percentage of large cells represented $10.85 \pm 1.13 \%, 15.70 \pm 2.50 \%$, and $12.50 \pm$ $3.10 \%$ of total cells from 15-, 25-day-old and PMSG-primed rats, respectively (Table 2 ). To avoid cross-contamination with small cells, the gate was placed on channel 28 for collecting further purified large-cell populations. The purity of large cells obtained by cell sorting was $83.6 \%$ in 15-day-old, $87.9 \%$ in 25 day-old, and $84.6 \%$ in PMSG-primed rats. The FALS- $90^{\circ}$ LS distribution analysis was performed on total pooled granulosa cells to determine whether there was a shift in $90^{\circ} \mathrm{LS}$ (cytoplasmic granularity) among the three groups of granulosa cell. The cell distribution patterns are shown (Fig. 3). For standard setting, the gates were placed on the cell distribution from 25-day-old rats for determining the percentage of cells that lay within regions $1-4$. The FALS gate was placed on channel 23 (equivalent to one-parameter analysis) and the $90^{\circ} \mathrm{LS}$ gate was placed on channel 33. Cellular debris and erythrocytes were excluded from analysis by placing the gate on channel 15 in quadrant 3. In 25day-old rats, small and large cells with high:low granularity were 0.37 and 1.85 (Table 3). Compared with 25-day-old rats, there were fewer small and large cells with high:low granularity in 15-day-old rats. However, the number of large cells with high granularity was dramatically increased in PMSG-primed rats compared with that of 25 -day-old rats (12.56 versus 1.85 ). These results indicated a shift in small and large cells with increased granularity from 15-day-old to PMSG-primed rats.

\section{Progesterone production by granulosa cells}

Functional integrity of the granulosa cells was demonstrated by secretion of progesterone into the culture medium (Fig. 3). For all groups, small or large cells cultured in basic medium for 3 days did not further increase their progesterone secretion, although the basal rate of production from large cells was greater than from small cells in PMSG-primed rats. Incubation in the presence of FSH or TGF- $\alpha$ increased the amount of progesterone. Throughout the culture period, FSH plus TGF- $\alpha$ induced the highest concentrations of progesterone in all groups. Small and large granulosa cells from 15-day-old rats did not respond to the stimulants and secreted low concentrations of progesterone (FSH/TGF- $\alpha 4.69 \pm 1.2$ versus $2.66 \pm$ $1.0 \times 10^{-6} \mathrm{ng}$, day 1). In 25-day-old rats, incubation in the presence of FSH, TGF- $\alpha$ or both resulted in increased concentration of progesterone with both types of cell producing similar amounts of progesterone (FSH/TGF- $\alpha 65.68 \pm 9.6$ versus 

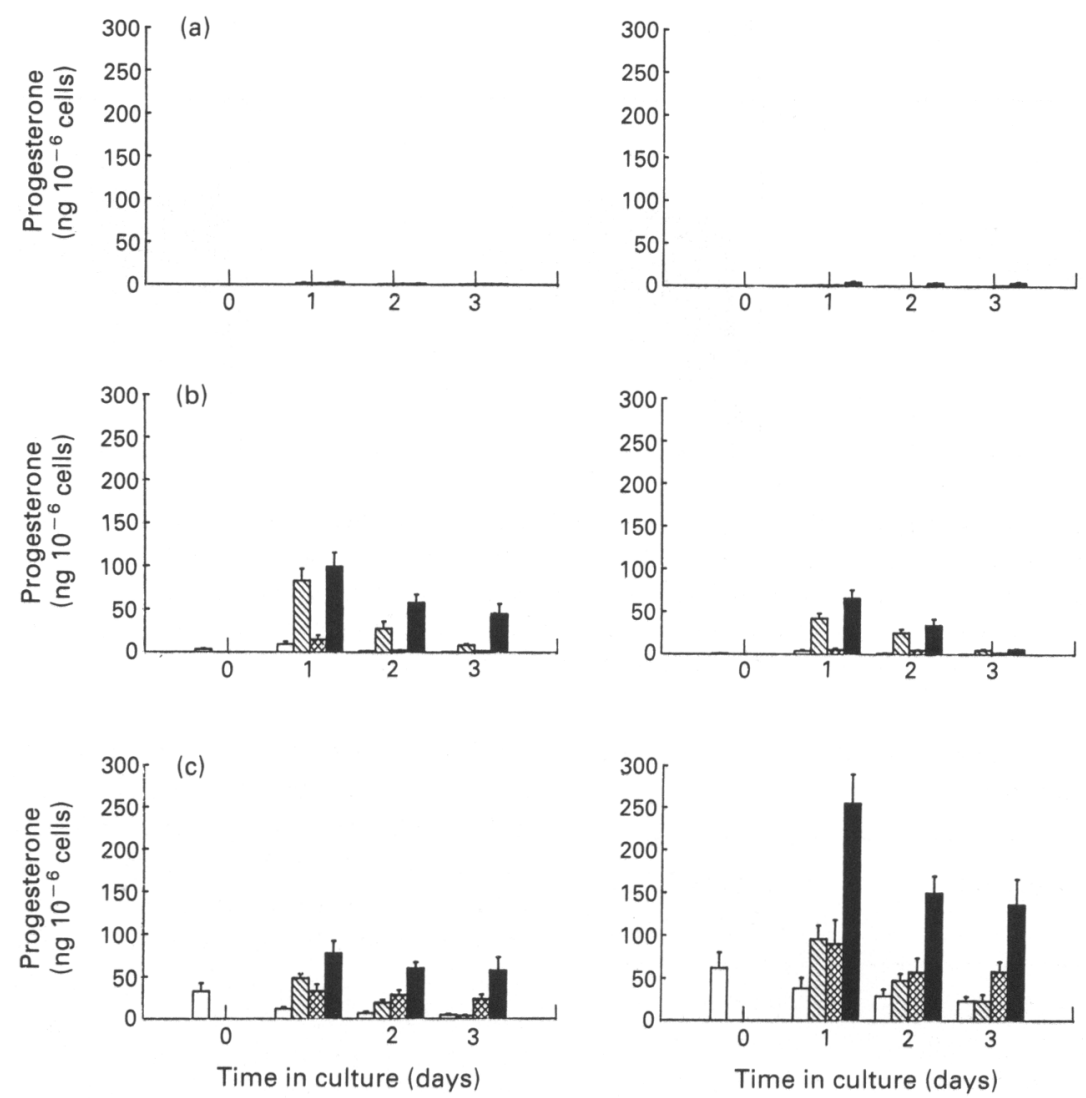

Fig. 3. Progesterone production of small (left) and large (right) cells from (a) 15-day-old, (b) 25-day-old and (c) PMSG-primed rats. Granulosa cells were cultured with (\$) $50 \mathrm{ng}$ FSH ml ${ }^{-1}$, $10 \mathrm{ng} \mathrm{TGF-} \alpha \mathrm{ml}^{-1}$ or ( $\mathbf{\square}$ ) a combination of both for 3 days; ( $\square$ ) control.

$78.25 \pm 12.3 \times 10^{-6} \mathrm{ng}$, day 1). A different profile of progesterone production was obtained in the PMSG-treated group; large cells produced 3.2 times more progesterone than did small cells on day $1(P<0.05)$.

\section{Ultrastructure analysis}

Morphological integrity of granulosa cells was observed by electron microscopy. Ultrastructural studies revealed differences between the small and large cells. The intracellular organelles involved in steroidogenesis are lipid droplets, mitochondria, lysosomes and smooth endoplasmic reticulum. At the time of harvest and separation by Percoll, there were few structural differences between the two types of cells (Fig. 4a, b). The small cells had many more lipid droplets in close association with mitochondria. Cytoplasmic changes and development of organelles associated with steroidogenesis were confirmed only in cultured granulosa cells from PMSG-primed rats. The abundant smooth endoplasmic reticulum (SER), well-developed mitochondria and lipid droplets were observed in large cells (Fig. 5a,b). After 3 days of culture, the large cells but not the small cells contained mitochondria with tubular cristae when cultured in the presence of FSH plus TGF- $\alpha$ (Fig. 6a, b). This morphological change in mitochondrial structure may represent luteinization of granulosa cells since mitochondria with tubular cristae are features of the corpus luteum (Anderson and Little, 1985).

Large and small granulosa cells from 15-day-old rats were structurally homogeneous (Fig. 7a, b).

\section{Discussion}

Our study shows that ovarian follicles of 15-day-old, 25-dayold and PMSG-primed rats have populations of large and small granulosa cells the morphological and physiological features of which are related to their response to FSH, TGF- $\alpha$ or both substances. These characteristics may be related to the transition from the preantral to the preovulatory stage of follicle differentiation.

The heterogeneity in granulosa populations is related to cell location within the follicle (Magnusson et al., 1982). The two granulosa cell populations are functionally different from each other in that the mural granulosa cells contain higher concentrations of $\Delta^{5}-3 \beta$-hydroxysteroid dehydrogenase and glucose6-phosphate dehydrogenase activity (Zoller and Weisz, 1979). Amsterdam et al. (1975) found that labelled-binding sites for hCG are located over the mural granulosa cells adjacent to the basement membrane, but that labelling decreased towards the inner layers of the granulosa cells in the follicle. Using the method of $\left[\mathrm{H}^{3}\right]$ thymidine incorporation, Hirshfield (1986) found 

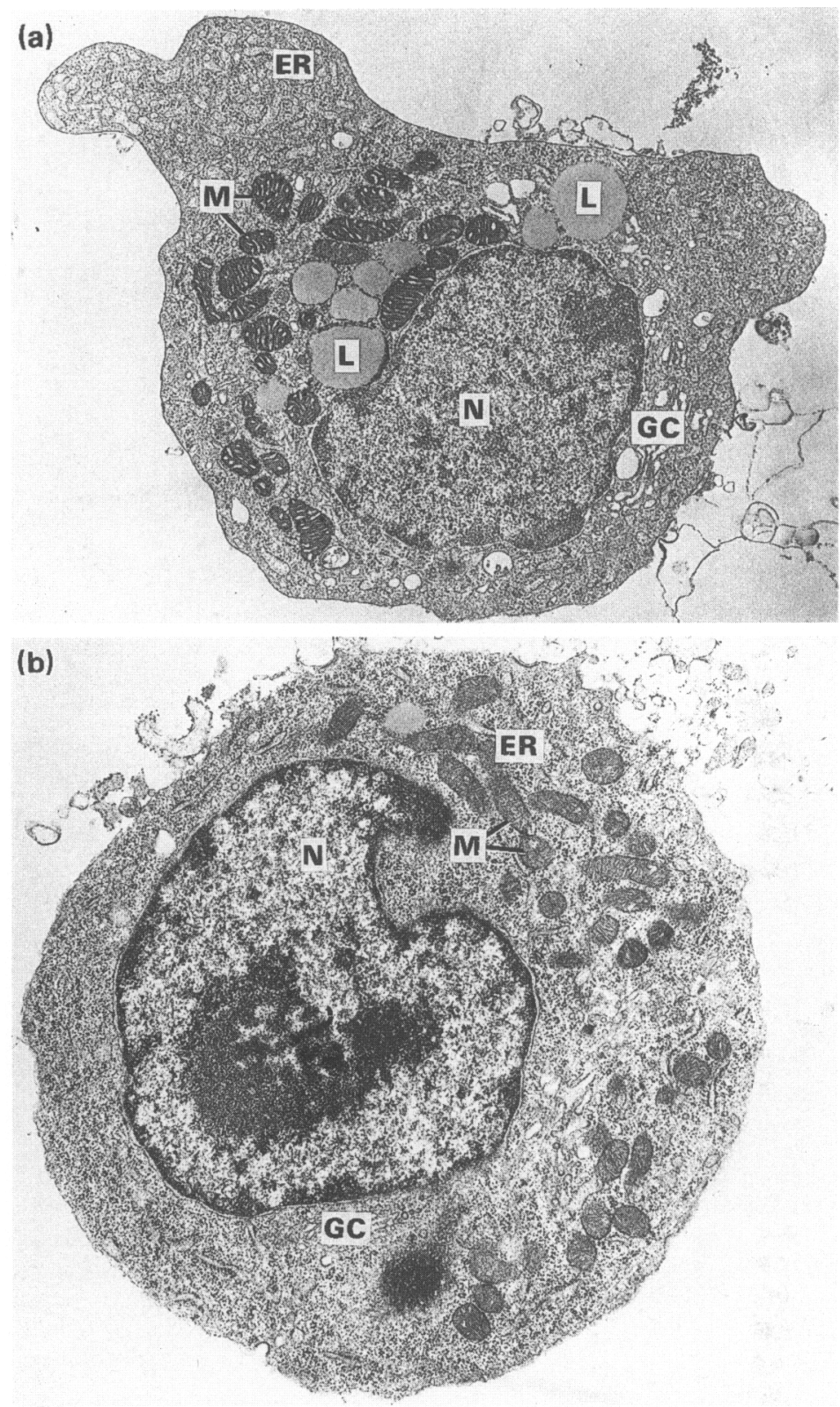

Fig. 4. (a) A small granulosa cell and (b) a large granulosa cell from a PMSGprimed rat follicle. ER: rough endoplasmic reticulum; M: mitochondria; L: lipid droplets; GC: Golgi complex; N: nucleus; $\times 8400$.

that mural granulosa cells were more differentiated than antral granulosa cells.

A high degree of purity of the cell populations is necessary to study the individual function of the two types of granulosa cell. We have used a combination of density gradients and flow cytometry. Prior separation by Percoll gradient allowed purification of small-cell populations (84.5-94.1\%). Separation by Percoll gradient eliminated cellular debris and erythrocytes, minimized the sorting time, and enhanced the recovery of granulosa cells. In large-cell preparations (fractions 3 and 4) obtained by Percoll gradient, large cells contained 39.1-65.0\% of the total number of cells, whereas the purity of the large cells obtained by flow cytometry was $83.6-87.9 \%$. In agreement with the method described by Alila et al. (1988), this combined method improved the purity of large-cell preparations. However, compared with their large luteal cell preparations $(90-$ $99 \%$ ), the purity of large granulosa cells in our study was low, possibly due to the narrow separation between the small-cell diameter range of $6.96-9.57 \mu \mathrm{m}$ and the large-cell diameter range of $10.96-13.05 \mu \mathrm{m}$.

The FALS $-90^{\circ} \mathrm{LS}$ distribution analysis by flow cytometry measures the granularity of cells as well as relative cell size. Since $90^{\circ} \mathrm{LS}$ signals reflect cytoplasmic elements, such as certain organelles, the increased signals indicated a higher degree of maturation (Rao et al., 1991). This analysis determined whether the granularity of granulosa cells was changed among the three 

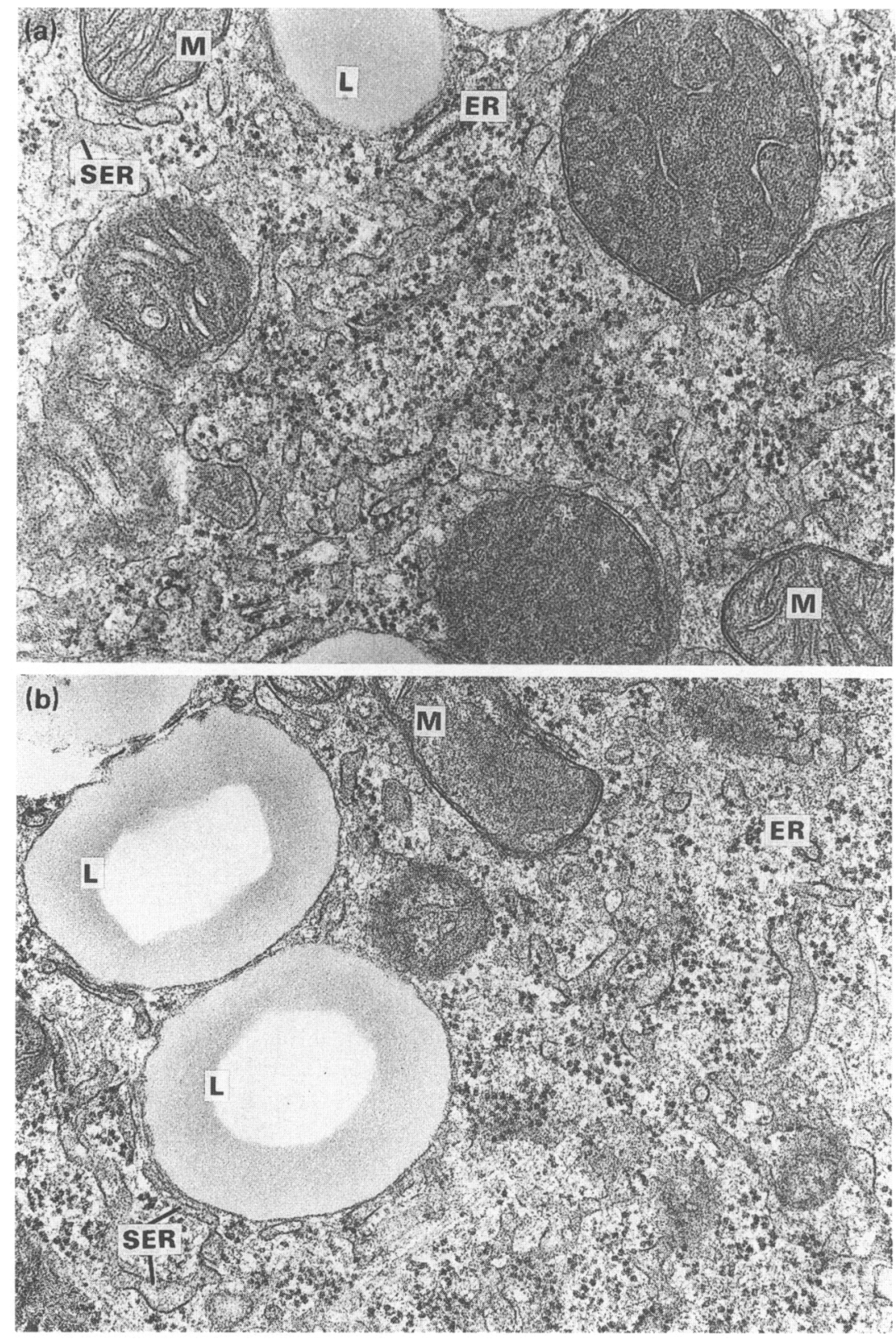

Fig. 5. A small portion of (a) a small cell and (b) a large cell from a PMSG-primed rat follicle cultured for 1 day. SER: smooth endoplasmic reticulum; ER: rough endoplasmic reticulum; L: lipid droplet; $\mathrm{M}$ : mitochondria; $\times 48000$.

experimental groups. A shift in small and large cells with increased granularity from 15-day-old to PMSG-primed rats was observed. Large cells from PMSG-primed rats dramatically increased in granularity compared with those from 25-day- and 15-day-old rats. Electron microscopy allowed the structural composition of these granulosa cells to be examined, but the results showed few structural differences among these granulosa cells. Changes in cytoplasmic structures within the granulosa cells were observed after they were placed into culture.

The functional integrity of the granulosa cells was demonstrated by secretion of progesterone during culture. The two subpopulations of granulosa cell responded differently to FSH and TGF- $\alpha$ stimulation. Unpublished observations from our laboratory revealed that TGF- $\alpha$ stimulated protein synthesis. As shown in the present study, TGF- $\alpha$ promoted the production of progesterone. It is possible that certain differentiated states of granulosa cells respond differently to TGF- $\alpha$ when in combination with FSH. The synthesis of TGF- $\alpha$ by rat granulosa cells (Yeh et al., 1991; 1993) or theca cells (Kudlow et al., 1987) suggests a paracrine and autocrine role in the regulation of granulosa cell function. TGF- $\alpha$ promotes cell proliferation (Skinner and Coffey, 1988) and may have a role in modulating hormone action on granulosa cells (Adashi et al., 1987). As with 

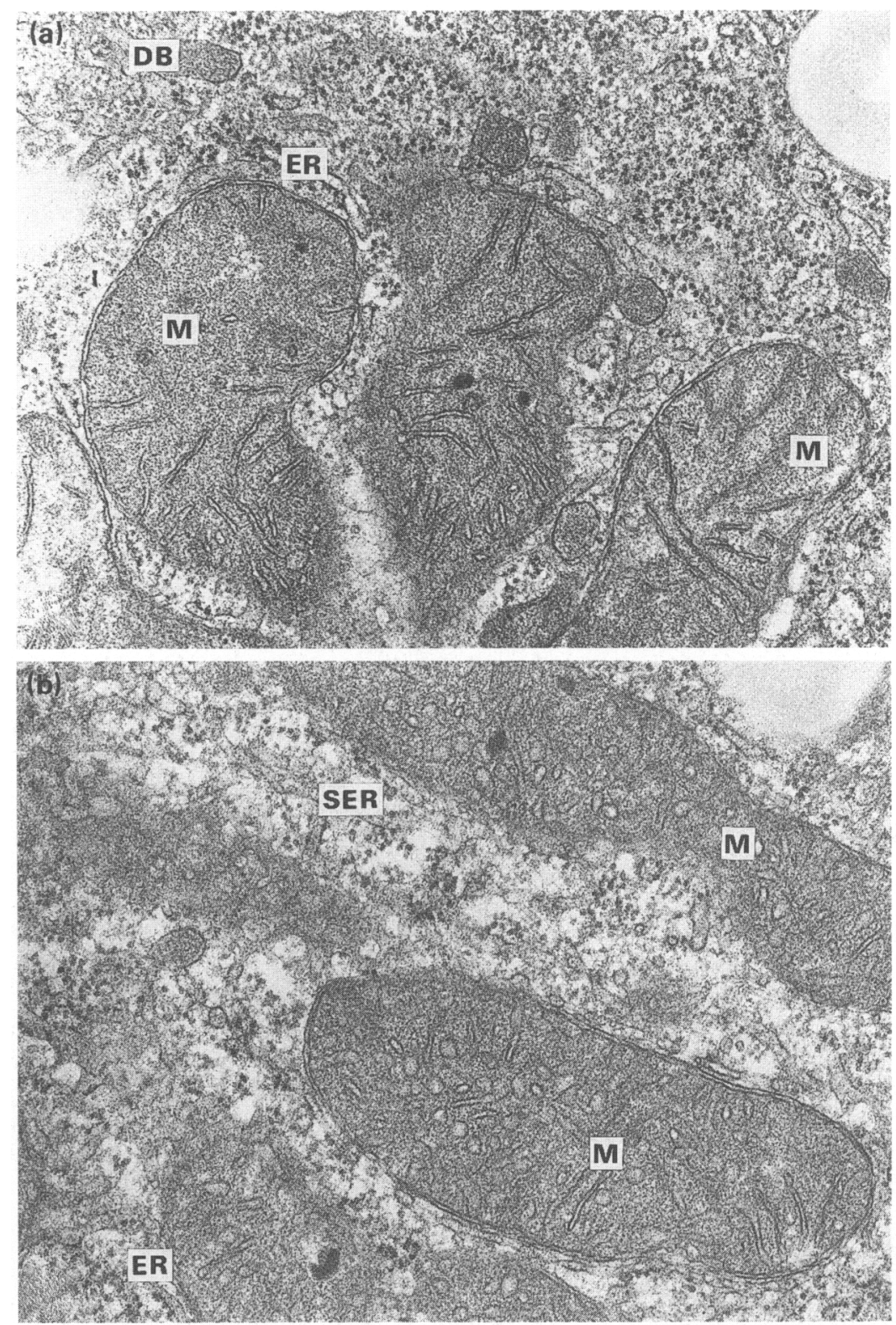

Fig. 6. A small portion of (a) a small cell and (b) a large cell from a PMSG-primed rat follicle cultured for 3 days. ER: rough endoplasmic reticulum; SER: smooth endoplasmic reticulum; $\mathrm{DB}$; dense bodies; $\mathrm{M}$ : mitochondria; $\times 48000$.

epidermal growth factor (EGF) (Jones et al., 1982), TGF- $\alpha$ plus FSH can enhance progesterone production by granulosa cells (Yeh $e$ al., 1991; 1993). The regulatory role of TGF- $\alpha$ in the growth and differentiation of granulosa cells may occur within the ovary (Kudlow et al., 1987). The results of the study reported here demonstrate a differential control of progesterone production in small and large granulosa cells from PMSGtreated rats. Large cells are maximally responsive to stimulation by FSH plus TGF- $\alpha$ on day 1 of culture as indicated by progesterone secretion. Electron microscopy of the granulosa cells indicated regional differences in cell morphology. The abundant smooth endoplasmic reticulum, well-developed mitochondria and lipid droplets observed in large cells are characteristics of high steroidogenic activity (Amsterdam and Rotmensch, 1987).
After 3 days of culture, the large cells, but not the small cells, contain mitochondria with tubular cristae that were observed in the presence of FSH plus TGF- $\alpha$. Such morphological changes are consistent with luteinization of the granulosa cells. As FSH alone did not induce this apparent luteinization in serum-free medium (Orly et al., 1980), FSH plus TGF- $\alpha$ can induce or enhance luteinization of the large granulosa cells. These results together with the progesterone production indicate that large cells are functionally differentiated cells. As the large cells account for only $10.85-15.70 \%$ of the total granulosa cell population, the mechanism by which large cells are involved in follicular function is not known. Rodgers $e$ t al. (1985) suggested a paracrine interaction between subpopulations of luteal cells from sheep. It is possible that separation of cells into subpopu- 

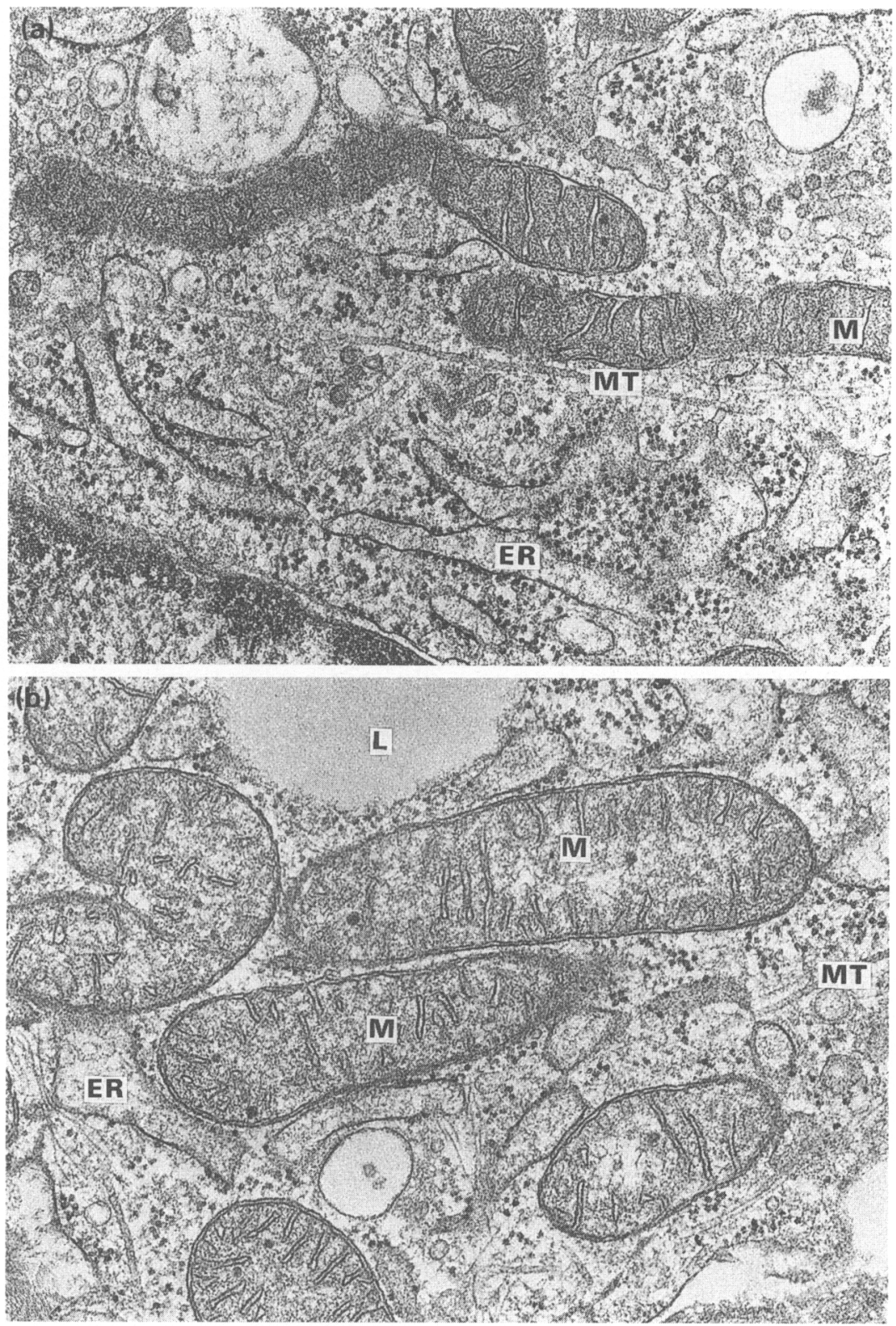

Fig. 7. A small portion of (a) a small cell and (b) a large cell from a 15-day-old rat follicle cultured for 3 days. ER: rough endoplasmic reticulum; M: mitochondria; MT: microtubule; L: lipid droplets; $\times 48000$.

lations might alter interactions between the two cell types that influence steroidogenic responses. In contrast, small and large cells from 25-day-old rats respond in a very similar way to FSH and TGF- $\alpha$ stimulation. Granulosa cells from 15-day-old rats were not responsive to these stimulations and secreted very low concentrations of progesterone. These observations correlate with our electron microscope analysis which demonstrated that small and large cells are structurally homogeneous cells. The steroidogenic potential of these granulosa cells could be due to degrees of differentiation; granulosa cells from 15-day-old rats are preantral, from PMSG-treated rats are preovulatory and from 25-day-old rat follicles are intermediate. It is most likely that the states of the microenvironments within all follicles are quite different and would be expected to affect granulosa cell differentiation during follicle development. Depending upon the stage of follicular development, granulosa cells vary markedly in their response to hormonal stimuli and their ability to secrete steroid hormones (Channing, 1970). Our findings have shown that metabolic and morphological features of large cells are associated with follicular development. The question is therefore raised as to whether there is movement of cells between the two subpopulations. The possibility that small cells are precursors of large cells cannot be ruled out. However, it is unlikely that all of the large cells arise from the small cells, as the percentage of large cells is not significantly different among granulosa cells from the different stages of follicles. In agreement with the observations of Rao et al. (1991), this finding could indicate that the two types of granulosa cell are 
independent populations and have different cell cycles. It is also possible that the two populations may be a constant feature since there are also two populations of luteal cells not only in the corpus luteum of rats (Wilkinson et al., 1976) but also in the corpora lutea of other species (Fitz et al., 1982). However, Alila and Hansel (1984) claimed that the small cells of the bovine corpus luteum are of 'thecal origin'. It must be emphasized that functional differentiation of granulosa cells during transition from the preantral to preovulatory follicle stage is to be expected and that the metabolic properties of small and large cells correlate with the stages of follicle development.

This investigation is supported by research grants HD-06645 (LHRRB Center grant) and HD-14574 (to EA) from the National Institute of Child Health and Human Development, NIH. Thanks are extended to $\mathrm{S}$. Chinkham for her general technical assistance, B. Ernisse for assistance with radioimmunoassay, P. Ropez for assistance with flow cytometry, and S. Borack for photographic assistance. Animals used in this study were maintained in accordance with the guidelines of the Animal Resources Center at the Harvard University School of Medicine and those prepared by the Committee on Care and Use of Laboratory Animals of the Institute of Laboratory Resources, National Research Council, DHHS Publication No. (NIH) 85-23, revised 1985.

\section{References}

Adashi EY, Resnick CE and Twardzik DR (1987) Transforming growth factor- $\alpha$ attenuates the acquisition of aromatase activity by cultured rat granulosa cells Journal of Cellular Biochemistry 33 1-13

Alila HW and Hansel W (1984) Origin of different cell types in the bovine corpus luteum as characterized by specific monoclonal antibodies Biology of Reproduction 31 1015-1025

Alila HW, Dowd JP, Corradino RA, Harris WV and Hansel W (1988) Control of progesterone production in small and large bovine luteal cells separated by flow cytometry Joumal of Reproduction and Fertility 82 645-655

Amsterdam A and Rotmensch S (1987) Structure-function relationships in the differentiating granulosa cell Endocrine Reviews 8 309-337

Amsterdam A, Koch Y, Lieberman E and Lindner HR (1975) Distribution of binding sites for human chorionic gonadotropin in the preovulatory follicle of the rat Journal of Cell Biology $67894-900$

Anderson E and Lee GY (1993) The participation of growth factors in simulating the quiescent, proliferative and differentiative stages of rat granulosa cells in a serum free medium Tissue and Cell 25 49-72

Anderson E and Little B (1985) The ontogeny of the rat granulosa cell. In Proceedings of the Fifth Biennial Ovarian Workshop, pp 203-226 Eds DO Toft and RJ Ryan. Ovarian Workshops, Champaign, IL

Anderson E, Little B and Lee GS (1987) Androgen-induced changes in rat ovarian granulosa cells in vitro Tissue and Cell 19 217-234

Buccione R, Vanderhyden BC, Caron PJ and Eppig JJ (1990) FSH-induced expansion of the mouse cumulus oophorus in vitro is dependent upon a specific factor(s) secreted by the oocyte Developmental Biology 138 16-25

Channing CP (1970) Influence of the in vivo and in vitro hormonal environment upon luteinization of granulosa cells in tissue culture Recent Progress in Hormone Research 26 589-622

diZerega GS and Hodgen G (1980) Fluorescence localization of luteinizing hormone/human chorionic gonadotropin uptake on the primate ovary. II. Changing distribution during selection of the dormant follicle Journal of Clinical Endocrinology and Metabolism 51 903-907

Fitz TA, Mayan MH, Sawyer HR and Niswender GD (1982) Characterization of two steroidogenic cell types in the ovine corpus luteum Biology of Reproduction 27 703-711

Gale JS, Wakefield JStJ and Ford HC (1982) Isolation of rat Leydig cells by density gradient centrifugation Joumal of Endocrinology 92 293-302

Hartshorne GM (1990) Subpopulations of granulosa cells within the human ovarian follicle journal of Reproduction and Fertility 89 773-782

Hatfield JM and Hymer WC (1986a) Flow cytometric analysis and sorting of live male rat anterior pituitary cell types by forward angle and perpendicular light scatter Endocrinology 119 2670-2682
Hatfield JM and Hymer WC (1986b) Flow cytometric analysis and sorting of live female rat anterior pituitary cell types by forward angle and perpendicular light scatter: effect of $17 \beta$-estradiol Endocrinology $1192683-2694$

Hirshfield AN (1986) Patterns of [ $\left.{ }^{3} \mathrm{H}\right]$ thymidine incorporation differ in immature rats and mature, cycling rats Biology of Reproduction 34 229-235

Hirshfield AN, Flickinger GL and Ben-Rafael Z (1988) Flow cytometric analysis of granulosa cell proliferation in rats Joumal of Reproduction and Fertility 84 231-238

Jones PBC, Welsh TH, Jr and Hsueh AJW (1982) Regulation of ovarian progestin production by epidermal growth factor in cultured rat granulosa cells journal of Biological Chemistry 257 11268-11273

Koos RD and Hansel W (1981) The large and small cells of the bovine corpus luteum: ultrastructural and functional differences. In Dynamics of Ovarian Function, pp 197-203 Eds NB Schwartz and M Hunzicker-Dunn. Raven Press, New York

Kudlow JE, Kobrin MS, Purchio AF, Twardzik DR, Hernandez ER, Asa SL and Adashi EY (1987) Ovarian transforming growth factor- $\alpha$ gene expression: immunohistochemical localization to the theca-interstitial cells Endocrinology 121 1577-1579

Lahteenmaki P, Lobo R, Marrs RP, Gibbons WE, Nakamura RM and diZerega GS (1982) Characterization of porcine granulosa cells by isopycnic gradient centrifugation Biology of Reproduction 27 633-640

Magnusson C, Billig H, Roos P and Hillensjo T (1982) Comparison between the progestin secretion responsiveness to gonadotrophins of rat cumulus and mural granulosa cells in vitro Acta Endocrinologica $101611-616$

Magoffin DA and Erickson GF (1988) Purification of ovarian theca-interstitial cells by density gradient centrifugation Endocrinology 122 2345-2347

Ohara A, Mori T, Taii S, Ban C and Narimoto K (1987) Functional differentiation in steroidogenesis of two types of luteal cells isolated from mature human corpora lutea of menstrual cycle Journal of Clinical Endocrinology and Metabolism 65 1192-1200

Orly J, Sato G and Erickson GF (1980) Serum suppresses the expression of hormonally induced functions in cultured granulosa cells Cell 20 817-827

Philips HJ (1973) Dye exclusion tests for cell viability. In Tissue Culture Method and Application, pp 406-408 Eds PF Kruse and MK Patterson. Academic Press, New York

Rao IM, Alisbrook WC, Jr, Conway BA, Martinez JE, Beck JR, Pantazis CG, Mills TM, Anderson E and Mahesh VB (1991) Flow cytometric analysis of granulosa cells from developing rat follicles Joumal of Reproduction and Fertility 91 521-530

Rodgers RJ, O'Shea JD and Findlay JK (1985) Do small and large luteal cells of the sheep interact in the production of progesterone? Journal of Reproduction and Fertility 75 85-94

Salustri A, Yanagishita M and Hascall VC (1990) Mouse oocytes regulate hyaluronic acid synthesis and mucification by FSH-stimulated cumulus cells Developmental Biology 138 26-32

Shapiro HM (1985) Practical Flow Cytometry Alan R. Liss, New York

Skinner MK and Coffey RJ, Jr (1988) Regulation of ovarian cell growth through the local production of transforming growth factor- $\alpha$ by theca cells Endocrinology 123 2632-2638

Snedecor GW and Cochran WG (1982) Statistical Methods Iowa State University Press, Ames

Telfer E, Ansell JD, Taylor H and Gosden RG (1988) The number of clonal precursors of the follicular epithelium in the mouse ovary joumal of Reproduction and Fertility 84 105-110

Vanderhyden BC, Carson PJ, Buccione R and Eppig JJ (1990) Developmental pattern of the secretion of cumulus expansion enabling factor by mouse oocytes and the role of oocytes in promoting granulosa cell differentiation Developmental Biology 140 307-317

Wilkinson RF, Anderson E and Aalberg J (1976) Cytological observations of dissociated rat corpus luteum Journal of Ultrastructure Research 57 168-184

Yeh J, Lee GY and Anderson E (1991) Presence of transforming growth factor alpha (TGF- $\alpha$ ) mRNA and absence of epidermal growth factor (EGF) mRNA in rat ovarian granulosa cells in vitro Journal of Cell Biology $111368 \mathrm{a}$

Yeh J, Lee GY and Anderson E (1993) Presence of transforming growth factoralpha mRNA and absence of epidermal growth factor mRNA in rat ovarian granuiosa cells, and the effects of these factors on steroidogenesis in vitro Biology of Reproduction 48 1071-1081

Zoller LC and Weisz J (1979) A quantitative cytochemical study of glucose-6phosphate dehydrogenase and $\Delta^{s}-3 \beta$-hydroxysteroid dehydrogenase activity of the membrana granulosa of the ovulable type of follicle of the rat Histochemistry 62 125-135 